Article

\title{
Antibiofilm and Enzyme Inhibitory Potentials of Two Annonaceous Food Spices, African Pepper (Xylopia aethiopica) and African Nutmeg (Monodora myristica)
}

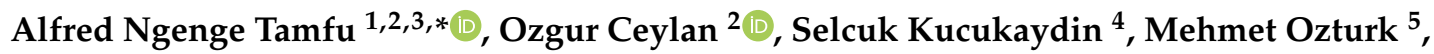 \\ Mehmet Emin Duru ${ }^{5}$ and Rodica Mihaela Dinica ${ }^{3, *}$ \\ 1 Department of Chemical Engineering, School of Chemical Engineering and Mineral Industries, \\ University of Ngaoundere, Ngaoundere 454, Cameroon \\ 2 Food Quality Control and Analysis Program, Ula Ali Kocman Vocational School, \\ Mugla Sitki Kocman University, 48147 Ula Mugla, Turkey; ozgurceylan@mu.edu.tr \\ 3 Department of Chemistry Physical and Environment, Faculty of Sciences and Environment, \\ “Dunarea de Jos" University of Galati, 111 Domneasca Street, 800201 Galati, Romania \\ 4 Department of Medical Services and Techniques, Koycegiz Vocational School of Health Services, \\ Mugla Sitki Kocman University, 48800 Mugla, Turkey; selcukkucukaydin@gmail.com \\ 5 Department of Chemistry, Faculty of Science, Mugla Sitki Kocman University, 48000 Mugla, Turkey; \\ mehmetozturk@mu.edu.tr (M.O.); eminduru@mu.edu.tr (M.E.D.) \\ * Correspondence: macntamfu@yahoo.co.uk (A.N.T.); rodica.dinica@ugal.ro (R.M.D.); \\ Tel.: +237-675590353 (A.N.T.); +33-6130-251 (R.M.D.)
}

Received: 29 October 2020; Accepted: 27 November 2020; Published: 29 November 2020

\begin{abstract}
Food pathogens represent an important health threat, and it is relevant to study the effect of foodstuffs such as spices which can inhibit bacterial growth. This study reports the antimicrobial, antibiofilm, and enzyme (Acetylcholinesterase, Butyrylcholinesterase, urease, tyrosinase) inhibitory activities of two medicinal food spices belonging to the Annonaceae family, Monodora myristica and Xylopia aethiopica. GC-MS (gas chromatography mass spectrometry) analysis of silylated samples of Methanol-Dicloromethane (50:50) extracts of both plants led to the identification of nine compounds in M. myristica and seven compounds in X. aethiopica. M. myristica and X. aethiopica had the same minimum inhibitory concentration (MIC) values of $0.625 \mathrm{mg} / \mathrm{mL}$ and $2.5 \mathrm{mg} / \mathrm{mL}$ on C. albicans and E. coli, respectively. However, M. myristica had better activity than X. aethiopica on Staphylococcus aureus, while Pseudomonas aeruginosa was more susceptible to X. aethiopica than M. myristica. The lowest MIC value was $0.1325 \mathrm{mg} / \mathrm{mL}$, exhibited by M. myristica on S. aureus. Both extracts showed good antibiofilm activity. On S. aureus, at the same concentration, M. myristica had better antibiofilm activity than X. aethiopica. On E. coli and Candida albicans, X. aethiopica had better antibiofilm activity than M. myristica at the same concentration. X. aethiopica showed better violacein inhibition in Chromobacterium violaceum CV12472, as its percentage inhibition of violacein varied from $80.5 \% \pm$ $3.0 \%$ at MIC to $5.6 \pm 0.2$ at MIC/8, as compared to M. myristica with $75.1 \% \pm 2.5 \%$ at MIC and $15.5 \% \pm$ $1.1 \%$ at MIC/8. The anti-motility activity by swimming and swarming inhibition on P. aeruginosa PA01 was low at test concentrations and in both models, M. myristica showed higher motility inhibition than X. aethiopica. Although in enzyme inhibitory assays all extracts had low inhibitions compared to standards tested at the same concentrations, the results show that these plants can be used to manage food-borne infections.
\end{abstract}

Keywords: African food spices; GC-MS (gas chromatography mass spectrometry); antimicrobial; antibiofilm; violacein inhibition; swarming inhibition; swimming inhibition; anticholinesterase; antiurease; antityrosinase 


\section{Introduction}

In every region of the world, selected indigenous plants are used as foods and spices, and investigating their chemical composition and bioactivities has become an interesting field of research. This is because it reveals both the nutritive value and medicinal potential of these food materials used as remedies especially for recalcitrant infectious diseases resulting from food contamination. Spices are defined by Corn et al. (1999) as ingredients usually from vegetables or different dried plant parts like barks, seeds, and leaves added in nutritionally small quantities to food in order to improve its color, taste, or flavor and may also play the role of preservatives that inhibit harmful bacterial growth [1,2]. Most spices are added to food recipes primarily for flavoring, seasoning, and imparting aroma to foods rather than for their nutritional benefits, and for this reason, their phytochemical compositions as well as bioactivities are still under-studied [3]. There is need for the search of locally available nutritional food excipients in Africa and other low income countries which are plagued with poor nutrition [4]. Xylopia aethiopica and Monodora myristica are two widely consumed food spices in Africa and both belong to the Annonaceae family of plants and have proven to be potent in managing microbial and fungal infections [5]. Annonaceous plants are commonly called custard apples and comprises over 2300 species which possess good biological activities [6].

$X$. aethiopica, also called African pepper, is a highly consumed food spice in Africa and it is used traditionally to manage rheumatism, bronchitis, headache, asthma, stomach-aches, neuralgia, dysenteric conditions, wounds and sores, constipation, epilepsy, fertility, and the ease of childbirth [7]. It has been shown to possess anticancer, antidiabetic, antimalarial, antioxidant, enzyme inhibitory, antimicrobial, and antibacterial properties and also protects against liver and kidney damage [3,7-14].

Monodora myristica, also called African nutmeg, bears many fruits. The seeds of this plant are mostly used in dry powdered form which is used as spice in desserts, stews, soups, and cakes. It is also marketed as whole seeds. These plants' seeds and powders are used in repelling insects, as a stimulant, and as remedy for sores, headache, and stomach disorders. In medicine, the bark is used in treatments of stomachaches, febrile pains, eye diseases, and hemorrhoids $[15,16]$. This plant possesses antioxidant, antisplasmodic, antiulcer, antimicrobial, cytotoxic, antinociceptive, anti-inflammatory, anticancer, and hepatoprotective activities, and it has been proven in male Wistar rats with induced hypercholesterolemic to modulate lipid peroxidation and bring down cholesterol levels [3,17-25].

These plants have been reported to possess antimicrobial activities, with more emphasis on their essential oil and little information about their extracts, meanwhile the plant seeds are consumed in whole. No studies have reported the ability of these plants to inhibit quorum-sensing-mediated effects in bacteria such as biofilm, violacein production, and swarming and swimming motilities. The aim of this work is to evaluate the ability of M. myristica and X. aethiopica extracts to inhibit biofilm formation, violacein production, and swimming and swarming motilities, as well as acetylcholinesterase, butyrylcholinesterase, urease, and tyrosinase enzymes.

\section{Materials and Methods}

\subsection{Plant Material and Extraction}

The seeds of Xylopia aethiopica and Monodora myristica were purchased from the Bamenda food market. Both spicy plants were identified by Mr. T. Fulbert, a botanist working at the National Herbarium of Cameroon and compared with existing voucher specimens 28725/SRF Cam. (X. aethiopica) and 49544/HNC (M. myristica). Of each of the seeds, $200 \mathrm{~g}$ were powdered and subjected to maceration extraction. Then, $2 \mathrm{~L}$ of dichloromethane/methanol mixture in the ratio 1:1 was used as the solvent for extraction process and the mixture was allowed to stand at room temperature for $48 \mathrm{~h}$ with intermittent stirring. After this, the supernatant was carefully decanted and filtered using a Whatman number 1 filter paper. This filtrate was evaporated on a Rotary evaporator to remove the solvent. This process was repeated three times for each sample to yield crude extracts of X. aethiopica $(27 \mathrm{~g})$ and M. myristica $(41 \mathrm{~g})$. 


\subsection{GC-FID (Gas Chromatography Flame Ionization Detector) and GC-MS Analyses}

Prior to the GC-MS analyses, the samples were silylated using BSTFA [bis (trimethylsilyl)-trifluoroacetamide], according to the method described by Talla and coworkers [26]. GC-FID and GC-MS were performed as described elsewhere [27]. The GC-MS profiles of the extracts were achieved on a gas chromatograph (Hewlett-Packard 5890, Bunker Lake Blvd, Ramsey, MN, USA) with a JEOL MS-600H mass spectrometer (Tokyo, Japan) as detector. Prior to this, GC-FID was performed on a Shimadzu GC-17(Shimadzu Corp., Kyoto, Japan). We used helium (1 mL/min) as the carrier gas at a split ratio of 1:10 in a SPB-5VR capillary column of length $30 \mathrm{~m}$ and inner diameter $0.25 \mathrm{~mm}$. The initial temperature of the oven was varied as follows: $60^{\circ} \mathrm{C}$ for $3 \mathrm{~min}$, increased at the rate of $5{ }^{\circ} \mathrm{C} / \mathrm{min}$ to $180^{\circ} \mathrm{C}$, and finally at $7{ }^{\circ} \mathrm{C} / \mathrm{min}$ to $300^{\circ} \mathrm{C}$ final temperature. A ZB-5MSVR column of $30 \mathrm{~m}$ length and $0.25 \mathrm{~mm}$ inner diameter was used for GC-MS and the same temperature conditions as for GC-FID were applied. Next, $250{ }^{\circ} \mathrm{C}$ and $70 \mathrm{eV}$ was applied for the ion source. Mass spectral fingerprints were used for identification on the NIST library and compared with some data reported.

\subsection{Determination of MIC (Minimal Inhibitory Concentration)}

The bacterial and fungal strains Staphylococcus aureus (ATCC 25923), Escherichia coli (ATCC 25922), Candida albicans (ATCC 10239), Chromobacterium violaceum (CV12472), and Pseudomonas aeroginosa (PA01) were used.

The broth dilution method, as described by the CLSI (Clinical and Laboratory Standards Institute, 2006), was applied to determine the MIC values [28]. The lowest concentration of extract at which no bacterial growth was visible was considered as the MIC. Mueller-Hinton Broth (MHB) was used as the medium and the bacterial concentration used had a density of $5 \times 10^{5}$ colony-forming units $(\mathrm{CFU}) / \mathrm{mL}$. Into 96-well microtiter plates, containing extracts at concentrations $(10,5,2.5,1.25,0.625,0.312 \mathrm{mg} / \mathrm{mL})$, $100 \mu \mathrm{L}$ of microbial cell solutions were inoculated and incubated for $24 \mathrm{~h}$ at $37^{\circ} \mathrm{C}$, after which the MICs were determined and recorded.

\subsection{Assay of Inhibition of Bacterial Biofilm Formation by Extracts}

The ability of the extracts to prevent biofilm formation by bacteria (S. aureus, E. coli and C. albicans) was evaluated at concentrations of 1,1/2,1/4,1/8, and 1/16 (MIC) using the microplate antibiofilm method [29]. Tryptose-Soy Broth (TSB) containing $0.25 \%$ glucose were filled into wells with or without extracts, and $200 \mu \mathrm{L}$ of $1 \%$ overnight bacterial cell cultures $\left(5 \times 10^{5} \mathrm{CFU} / \mathrm{mL}\right)$ were added and incubated at $37^{\circ} \mathrm{C}$ for $48 \mathrm{~h}$. The negative control wells contained only TSB and bacterial cells. The planktonic bacteria were washed after incubation, and the remaining bacteria were stained with $0.1 \%$ crystal violet solution and allowed to sit for $10 \mathrm{~min}$. The dye was washed out carefully with distilled water, after which $200 \mu \mathrm{L}$ of ethanol or 33\% glacial acetic were filled into the wells of the microplates. Next, $125 \mu \mathrm{L}$ of the resulting solution were transferred using a pipette into sterile tubes and the total volume was made up to $1 \mathrm{~mL}$ by adding distilled water. The optical density of each tube was read at $550 \mathrm{~nm}$, and the equation below was used to calculate the percentage inhibition of the biofilm formation. Each experiment was done three times.

$$
\text { Biofilm inhibition }(\%)=\frac{O D 550 \text { control }- \text { OD } 550 \text { sample }}{O D 550 \text { control }} \times 100
$$

\subsection{Violacein Pigment Inhibition Assay}

This assay measures the qualitative quorum-sensing potential of the extracts using Chromobacterium violaceum ATCC 12472 strain [30]. C. violaceum CV12472 was grown overnight and $10 \mu \mathrm{L}$ of it were put into microtiter sterile plates filled with $200 \mu \mathrm{L}$ of LB broth. Sub-MIC concentrations of extracts were added and then incubated at $30^{\circ} \mathrm{C}$ for $24 \mathrm{~h}$. Control plates contained only LB broth and C. violaceum ATCC 12472. The decrease in the production of violacein pigment was measured by taking the absorbance at $585 \mathrm{~nm}$. The violacein inhibition percentage of the extracts were calculated as follows: 


$$
\text { Violacein pigment inhibition }(\%)=\frac{O D 585 \text { control }- \text { OD } 585 \text { sample }}{O D 585 \text { control }} \times 100
$$

\subsection{Swimming and Swarming Motility Inhibition on Pseudomonas Aeruginosa PA01}

The ability of the extracts to inhibit swarming motility in P. aeruginosa PA01 was performed as described elsewhere [30]. Briefly, swarming plates consisting of, $0.5 \% \mathrm{NaCl}, 1 \%$ peptone, $0.5 \%$ agar, and $0.5 \%$ D-glucose together with extracts at three concentrations of 50,75 , and $100 \mu \mathrm{g} / \mathrm{mL}$ were prepared. P. aeruginosa PAO1 was grown overnight and $5 \mu \mathrm{L}$ of it were point-inoculated at the center, and the swarm plates were wrapped with paraffin and inoculated in an upright position for $18 \mathrm{~h}$. The plates not containing extracts were used as controls. The swarming movement was measured from the swarm diameter fronts.

The swimming plates consisted of $1.5 \%$ agar, $1 \%$ peptone, $0.5 \% \mathrm{NaCl}$, and $0.5 \% \mathrm{D}$-glucose together with the extracts at 50,75, and $100 \mu \mathrm{g} / \mathrm{mL}$ concentrations. The same bacteria P. aeruginosa PAO1 was inoculated as in the swarming model. The inoculation was done for $18 \mathrm{~h}$ and control plates did not contain extracts. Swim zone diameter for samples and controls were used in calculating the percentage inhibition of swimming motility.

\subsection{Cholinesterase Inhibition Assay}

Ellman's Method was used to evaluate the acetylcholinesterase (AChE) and butyrylcholinesterase (BChE) inhibition potential of extracts, and slight modifications were made [31]. Next, 96-well microplates were used and acetylthiocholine iodide $(0.71 \mathrm{mM})$ was the substrate in AChE assay, while butyrylthiocholine chloride $(0.2 \mathrm{mM})$ was the substrate for the BChE assay. In a 96 -well plate containing $150 \mu \mathrm{L}$ sodium phosphate buffer $100 \mathrm{mM}(\mathrm{pH}=8), 10 \mu \mathrm{L}$ of the sample were mixed with $20 \mu \mathrm{L}$ of enzymes AChE or BChE. The mixture was incubated at $25^{\circ} \mathrm{C}$ for $15 \mathrm{~min}$, after which $10 \mu \mathrm{L}$ of substrates and $10 \mu \mathrm{L}$ of Ellman's Reagent (DTNB $0.5 \mathrm{mM}$ ) were added and the volume made up to $200 \mu \mathrm{L}$. The absorbance was measured at $412 \mathrm{~nm}$ for $10 \mathrm{~min}$. The percentage inhibition of AChE or BChE was determined control using the formula:

$$
(\mathrm{E}-\mathrm{S}) / \mathrm{E} \times 100
$$

where:

E: activity of enzyme with control.

S: activity of enzyme with sample.

The experiments were repeated three times. Galantamine was used as the standard.

\subsection{Tyrosinase Inhibition Assay}

A spectrophotometrical method was used to evaluate the anti-tyrosinase activity of extracts in which tyrosinase enzyme from mushrooms was used following a method described elsewhere with a slight modification [32]. The substrate used in this assay was L-Dopa, while kojic acid was used as the standard inhibitor of tyrosinase. The percent inhibition of the enzyme (Inhibition \%) by the extracts was calculated at each sample concentration $(\mu \mathrm{g} / \mathrm{mL})$ in a similar manner as in the AChE and BChE assay.

\subsection{Urease Inhibition Assay}

The indophenol method, in which the production of ammonia is measured, was used to determine the potential of extracts to inhibit urease [33]. A mixture of $25 \mu \mathrm{L}$ of a Jack bean source urease enzyme, phosphate buffer $100 \mathrm{mM}$ (pH 8.2), and $50 \mu \mathrm{L}$ of urea $100 \mathrm{mM}$ was prepared and after the adding of the samples $(10 \mu \mathrm{L}, 1 \mathrm{mM})$, it was incubated for $15 \mathrm{~min}$ at $30{ }^{\circ} \mathrm{C}$. Subsequently, $45 \mu \mathrm{L}$ of phenol reagent $1 \%$ $(w / v)$ and $70 \mu \mathrm{L}$ of $0.005 \%(w / v)$ alkali reagent were both added into each well and the mixture further 
incubated for $50 \mathrm{~min}$. The standard used was Thiourea. The absorbances were recorded at $630 \mathrm{~nm}$ and the $\%$ inhibitions were calculated.

\subsection{Statistical Analysis}

Each activity was done in triplicate. The results were recorded as the means \pm standard error of the mean. Fisher's test was used to determine the significant differences between means; $p<0.05$ were regarded as significant.

\section{Results}

\subsection{GC-MS Chemical Composition}

Nine compounds (Figure 1), including 1-monolinoleoylglycerol, 6,9,12-octadecatrienoic acid benzyl ester, 3-hydroxyspirost-8-en-11-one, ethyl-3,4,5-trimethoxybenzoate, palmitic (hexadecanoic) acid, ursodeoxycholic acid and sugars such as glycerol, glucose, and sucrose were identified in M. myristica. On the other hand, seven compounds (Figure 2), were identified in X. aethiopica, these were 3-carene, eucalyptol, 2-hydroxy-4-methylbenzoic acid, abietic acid, 3,21-dihydroxypregnan-4-one alongside two sugars, fructose, and glucose.<smiles>CCCCC/C=C\C/C=C\CCCCCCCC(=O)OCC(O)CO</smiles>

1-monolinoleoylglycerol<smiles>OC[C@H]1O[C@H](O[C@]2(CO)O[C@H](CO)[C@@H](O)[C@H]2O)[C@H](O)[C@H](O)[C@@H]1O</smiles>

sucrose<smiles>CCOC(=O)c1cc(OC)c(OC)c(OC)c1</smiles>

Ethyl-3,4,5-trimethoxybenzoate<smiles>CC1CCC2(OC1)OC1CC3C4=C(C(=O)CC3(C)C1C)C1(C)CCC(O)CC1CCC42</smiles>

3-Hydroxyspirost-8-en-11-one<smiles>CCCCC/C=C\C/C=C\C/C=C\CCCCC(=O)OCc1ccccc1</smiles>

Benzyl-6,9,12-octadecatrienoate<smiles>CC(CCC(=O)O)C1CCC2C3C(O)CC4CC(O)CCC4(C)C3CCC12C</smiles>

Ursodeoxycholic acid<smiles>CCCCCCCCCCCCCCCC(=O)O</smiles>

Hexadecanoic acid<smiles>OC[C@H]1O[C@H](O)[C@@H](O)[C@H](O)[C@@H]1O</smiles>

Glucose<smiles>OCC(O)CO</smiles>

Glycerol

Figure 1. Chemical compounds identified in M. myristica seed extract by gas chromatography mass spectrometry (GC-MS). 
<smiles>CC12CCC(O)CC1CCC1C2CCC2(C)C(C(=O)CO)CCC12</smiles>

3,21-Dihydroxypregnan-20-one<smiles>OC[C@H]1O[C@H](CO)C(O)C1O</smiles><smiles>Cc1ccc(C(=O)O)c(O)c1</smiles>

Fructose
2-Hydroxy-4-methylbenzoic acid<smiles>CC(C)C1=CC2=CCC3C(C)(C(=O)O)CCCC3(C)C2CC1</smiles>

Abietic acid<smiles>OC[C@H]1O[C@H](O)[C@@H](O)[C@H](O)[C@H]1O</smiles>

Glucose

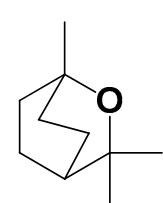

Eucalyptol<smiles>CC1=CCC2C(C1)C2(C)C</smiles>

3-Carene

Figure 2. Chemical compounds identified in X. aethiopica seed extract by GC-MS.

\subsection{Minimal Inhibitory Concentrations}

The minimal inhibitory concentrations (MICs) of both extracts are reported in Table 1. Both plants X. aethiopica and M. myristica had the same MIC values of $0.625 \mathrm{mg} / \mathrm{mL}$ and $2.5 \mathrm{mg} / \mathrm{mL}$ on C. albicans and E. coli, respectively. However, M. myristica had better activity than X. aethiopica on S. aureus, while P. aeruginosa was more susceptible to X. aethiopica than M. myristica. The lowest MIC value was $0.1325 \mathrm{mg} / \mathrm{mL}$, exhibited by M. myristica on S. aureus.

Table 1. Antimicrobial activities of X. aethiopica and M. myristica (minimum inhibitory concentration (MIC) values in $\mathrm{mg} / \mathrm{mL}$ ).

\begin{tabular}{ccc}
\hline \multirow{2}{*}{ Microorganisms } & \multicolumn{2}{c}{ Extracts } \\
\cline { 2 - 3 } & X. aethiopica & M. myristica \\
\hline C. albicans ATCC 10239 & 0.625 & 0.625 \\
\hline S. aureus ATCC 25923 & 0.625 & 0.3125 \\
\hline E. coli ATCC 25922 & 2.5 & 2.5 \\
\hline C. violaceum CV12472 & 2.5 & 1.25 \\
\hline P. aeruginosa PA01 & 0.625 & 1.25 \\
\hline
\end{tabular}

\subsection{Percentage Biofilm Inhibition}

Prior to antibiofilm assay, the MIC values were determined and the biofilm inhibition potential of both extracts determined at MIC and sub-MIC concentrations and reported in Table 2. Both extracts had good antibiofilm activity on S. aureus. On S. aureus, the biofilm inhibition of X. aethiopica varied from $45.3 \% \pm 1.5 \%$ at MIC to $5.2 \% \pm 1.0 \%$ at MIC/8 while that of $M$. myristica varied from $52.6 \% \pm 3.3 \%$ at MIC to $11.3 \% \pm 1.5 \%$ at MIC/8. On S. aureus, at the same concentration, M. myristica had better antibiofilm activity than X. aethiopica. On E. coli and C. albicans, X. aethiopica had better antibiofilm than M. myristica at the same concentration $(p<0.01)$. 
Table 2. Effects of different concentrations of X. aethiopica and M. myristica extracts on tested bacteria biofilm formations.

\begin{tabular}{|c|c|c|c|}
\hline \multirow{2}{*}{ Strains } & \multirow{2}{*}{ Conc. } & X. aethiopica & M. myristica \\
\hline & & \multicolumn{2}{|c|}{$\%$ of Biofilm Inhibition } \\
\hline \multirow{5}{*}{ S. aureus ATCC 25923} & MIC & $45.3 \pm 1.5^{*}$ & $52.6 \pm 3.3$ \\
\hline & $\mathrm{MIC} / 2$ & $30.0 \pm 3.4$ & $39.0 \pm 1.4$ \\
\hline & $\mathrm{MIC} / 4$ & $16.7 \pm 0.4$ & $23.8 \pm 0.6$ \\
\hline & $\mathrm{MIC} / 8$ & $5.2 \pm 1.0$ & $11.3 \pm 1.5$ \\
\hline & $\mathrm{MIC} / 16$ & - & - \\
\hline \multirow{5}{*}{ E. coli ATCC 25922} & MIC & $21.0 \pm 2.5$ & $18.6 \pm 0.5$ \\
\hline & $\mathrm{MIC} / 2$ & $10.5 \pm 0.5$ & $8.3 \pm 2.0$ \\
\hline & $\mathrm{MIC} / 4$ & - & - \\
\hline & $\mathrm{MIC} / 8$ & - & - \\
\hline & $\mathrm{MIC} / 16$ & - & - \\
\hline \multirow{5}{*}{ C. albicans ATCC 10239} & MIC & $31.7 \pm 1.5$ & $29.6 \pm 3.3$ \\
\hline & $\mathrm{MIC} / 2$ & $22.4 \pm 1.3$ & $15.3 \pm 0.1$ \\
\hline & $\mathrm{MIC} / 4$ & $09.2 \pm 0.5$ & $8.9 \pm 2.0$ \\
\hline & $\mathrm{MIC} / 8$ & - & - \\
\hline & MIC/16 & - & - \\
\hline
\end{tabular}

*: Data are the mean of three replicates \pm SD. Statistically different $(p<0.01)$.

\subsection{Violacein and Motility (Swimming and Swarming) Inhibition Percentages}

The percentage inhibition of violacein pigment synthesis by C. violaceum CV12472 was evaluated at MIC and sub-MIC concentrations and reported in Table 3. X. aethiopica inhibited violacein production better than M. myristica, as it percentage inhibition of violacein varied from $80.5 \% \pm 3.0 \%$ at MIC to $5.6 \pm 0.2$ at MIC/8 as compared to M. myristica with $75.1 \% \pm 2.5 \%$ at MIC and $15.5 \% \pm 1.1 \%$ at MIC/4 . At MIC/16, no inhibition was observed.

The swimming and swarming inhibition assay was carried on P. aeruginosa PA01 at $100 \mu \mathrm{g} / \mathrm{mL}$, $75 \mu \mathrm{g} / \mathrm{mL}$, and $50 \mu \mathrm{g} / \mathrm{mL}$, and the results are given in Table 3 . The anti-motility activity of these plant extracts were low at test concentrations. In both models, $M$. myristica showed higher motility inhibition than X. aethiopica $(p<0.05)$.

Table 3. Effects of X. aethiopica and M. myristica extracts at different concentrations on qualitative violacein inhibition and swarming/swimming motility.

\begin{tabular}{|c|c|c|c|c|}
\hline & \multicolumn{2}{|c|}{ X. aethiopica } & \multicolumn{2}{|c|}{ M. myristica } \\
\hline Conc. & \multicolumn{4}{|c|}{$\%$ of Violacein Inhibition (on C. violaceum CV12472) } \\
\hline MIC & \multicolumn{2}{|c|}{$80.5 \pm 3.0 *$} & \multicolumn{2}{|c|}{$75.1 \pm 2.5$} \\
\hline $\mathrm{MIC} / 2$ & \multicolumn{2}{|c|}{$37.3 \pm 0.7$} & \multicolumn{2}{|c|}{$35.8 \pm 0.6$} \\
\hline $\mathrm{MIC} / 4$ & \multicolumn{2}{|c|}{$19.4 \pm 1.0$} & \multicolumn{2}{|c|}{$15.5 \pm 1.1$} \\
\hline $\mathrm{MIC} / 8$ & \multicolumn{2}{|c|}{$5.6 \pm 0.2$} & \multicolumn{2}{|c|}{-} \\
\hline $\mathrm{MIC} / 16$ & \multicolumn{2}{|c|}{-} & \multicolumn{2}{|c|}{-} \\
\hline \multicolumn{5}{|c|}{$\%$ motility inhibition (on P. aeruginosa PA01) } \\
\hline Conc. $(\mu \mathrm{g} / \mathrm{mL})$ & Swimming inh. & Swarming inh. & Swimming inh. & Swarming inh. \\
\hline 100 & $25.1 \pm 0.5$ & $28.9 \pm 2.0$ & $29.2 \pm 0.0$ & $31.7 \pm 1.2$ \\
\hline 75 & $13.6 \pm 0.5$ & $12.0 \pm 0.5$ & $16.5 \pm 0.8$ & $22.3 \pm 1.0$ \\
\hline 50 & - & - & - & $11.6 \pm 0.5$ \\
\hline
\end{tabular}




\subsection{Enzyme Inhibitory Activities}

The capacity of X. aethiopica and M. myristica to inhibit some selected enzymes acetylcholinesterase, butyrylcholinesterase, tyrosinase, and urease are evaluated and reported in Table 4. On AChE, the activities of X. aethiopica $(7.80 \% \pm 0.36 \%)$ and M. myristica $(9.65 \% \pm 0.11 \%)$ were almost the same but far lower than that of the standard galantamine $(80.76 \% \pm 0.52 \%)$. This was the same effect for BChE on which percentage inhibitions of X. aethiopica and M. myristica were $15.48 \pm 0.57$ and $13.64 \pm$ 0.88 respectively against $74.43 \% \pm 0.30 \%$ for galantamine.

X. aethiopica $(30.45 \% \pm 0.84 \%)$ had better inhibition on tyrosinase than $M$. myristica $(23.44 \% \pm 1.27 \%)$ while on urease, $M$. myristica $(15.18 \% \pm 0.86 \%)$ was more active than X. aethiopica $(5.69 \% \pm 0.33 \%)$.

Table 4. Anticholinesterase, antityrosinase, and antiurease activities (\%inh.) of test samples at $100 \mu \mathrm{g} / \mathrm{mL}$.

\begin{tabular}{ccccc}
\hline \multirow{2}{*}{ Sample } & AChE & BChE & Tyrosinase & Urease \\
\cline { 2 - 5 } & \multicolumn{5}{c}{ \% Inhibition } \\
\hline X. aethiopica & $7.80 \pm 0.36$ & $15.48 \pm 0.57$ & $30.45 \pm 0.84$ & $5.69 \pm 0.33$ \\
\hline M. myristica & $9.65 \pm 0.11$ & $13.64 \pm 0.88$ & $23.44 \pm 1.27$ & $15.18 \pm 0.86$ \\
\hline Galantamine & $80.76 \pm 0.52$ & $74.43 \pm 0.30$ & $\mathrm{NT}$ & $\mathrm{NT}$ \\
\hline Kojic acid & $\mathrm{NT}$ & $\mathrm{NT}$ & $\mathrm{NT}$ & $67.58 \pm 0.23$ \\
\hline Thiourea & $\mathrm{NT}$ & $\mathrm{NT}$ & $75.17 \pm 0.18$ \\
\hline
\end{tabular}

\section{Discussion}

The chemical composition of both plant extracts were effected using GC-MS. The GC-MS was done after the samples were silylated to enable the detection of a large number of compounds including polar ones. Silylation helps to reduce polarity of compounds contained in the extract while equally rendering them more volatile such that they become detectable on GC-MS. These enabled the identification of major compounds in both extracts. These two plants investigated in this study have evidently been proven to possess antimicrobial activity and have been used extensively to manage infectious diseases [34], but much of this has been attributed to its essential oils [5] with little attention on the extracts. In this study, the extracts have also demonstrated appreciable antimicrobial activity, and this is advantageous, since the plants are consumed principally in crude form. Antimicrobial activity was displayed by both plant extracts and these results corroborate with some findings in which these plant extracts showed antimicrobial activity against some pathogens [35]. However, microbial resistance arises due to quorum-sensing-mediated traits of pathogens which determines the severity of infections as well. The assays that involved quorum-sensing-mediated processes in bacteria are usually focused biofilm formation, violacein pigment production, and swimming and swarming motilities. Prior to these assays, MIC values are determined and they are performed at MIC and sub-MIC concentrations. Thus, working at sub-MIC concentrations, the hypothesis of bactericidal effect of extracts that occurs at high concentrations is eliminated, giving way for QS investigation.

In order to protect themselves during adverse conditions such as immunological defense systems of host, antibiotics, and starvation, many fungi and bacteria cells constitute self-organized and three-dimensional communities in which they will live. These constituted and protected communities are called biofilms and they contribute to the severity of chronic infections as well as the persistence of resistance to drugs and antibiotics [6,36]. Therefore, most antimicrobial agents treat symptoms of planktonic bacteria, and disease will resurface, due to the bacteria which were within biofilms and which will break out when the threat from the antibiotic is over. The potential of these plant extracts to inhibit biofilm formation by test bacteria is a very desirable effect. This can subsequently eliminate bacteria resistance or reduce the severity of microbial infections. 
Violacein (violet color) production is one of the quorum-sensing-mediated traits of pathogenic bacteria $C$. violaceum that has received maximum attention and has the advantage that it is easily measurable and quantifiable. Violacein is a biomolecule that has antimicrobial activity against other microorganisms and also improves the $C$. violaceum's ability to cope with environmental stress $[37,38]$. C. violaceum has been highly applied in evaluating the antiinfective potential of many natural and synthetic products, and those with violacein inhibition find application potential alternatives to conventional bactericidal antibiotics.

The bacterial communities that are formed on surfaces constitute a serious health threat and potent contamination. The colonization of various surfaces by bacteria through bacterial motility can be reduced or limited by the use of natural substances and compounds which need to be identified and evaluated for their applications to impede bacterial colonizations [39]. Before forming biofilms, bacteria move by swimming and swarming and colonize surfaces, and this step is believed to be an initial step for the formation of the biofilm in flagellated P. aeruginosa PA01. This bacterium can use its flagella to swim towards surfaces followed by swarming and twitching motilities, which enables it to colonize surfaces and establish biofilm communities.

Cholinesterase inhibitors are a group of medicines that block the normal breakdown of acetylcholine. Deterioration of the central nervous system and Alzheimer's disease (AD) result from cholinergic deficiency and are associated with dementia. As a remedy to this situation, various cholinesterase inhibitors such as natural compounds and extracts and synthetic analogues and their hybrids are being employed [40]. Natural medicines are gaining ground because of their low toxicities and few side effects compared to synthetic ones. The enzyme-mediated browning reaction in harvested fruits is usually initiated by the copper-containing oxidase enzyme called tyrosinase. It is an enzyme with multiple functions and is responsible for the undesirable over-pigmentation of human skin in a process that is similar to that which takes place during the browning of fruits. The first two steps in mammalian melanogenesis are catalyzed by this enzyme, and hence the search for potent tyrosinase inhibitors, especially those that can be used safely in cosmetics and foods, is an attraction for researchers [41]. Many bacteria produce the nickel-dependent urease (ureolytic bacteria) enzyme, which is capable of hydrolyzing urea to produce ammonia with the emission of carbon dioxide as well. The emission of ammonia from agriculture is usually associated with these bacteria, and it also causes a number of infectious diseases [42]. Inhibiting urease is beneficial to human health and some notorious bacteria depend on urease-mediated processes for survival. Although in the enzyme inhibitory assays no extract had an inhibition close to that of the standards, these results are moderate because the extracts were tested at the same concentrations as the pure standard compounds.

Many of the compounds identified in these plants have previously been described in some medicinal plant extracts. 1-monolinoleoylglycerol, which is found in M. myristica has been described in the extract of Datura stramonium and Salvadora persica and the extracts of these plants have shown antimicrobial and anticancer activities [43,44]. Certain sugars were detected in both M. myristica and X. aethiopica plant extracts notably sucrose, glucose, glycerol, and fructose. These sugars were shown to possess antibacterial activities [45,46]. Ethyl-3,4,5-trimethoxybenzoate detected in M. myristica and other derivatives of 3,4,5-trimethoxybenzoic acid have been identified in medicinal plant Mitracarpus scaber and have demonstrated antimicrobial properties [47], and Anarcadium occidentale (cashew gum) also has been synthesized and evaluated for antioxidant and enzyme inhibition [48]. 6,9,12-octadecatrienoic acid phenylmethyl ester was found in the extract of M. myristica, and this compound was detected in Croton bonplandianum extract which possesses anti-inflammatory and enzyme inhibitory potentials [49]. 3-hydroxyspirost-8-ene-11-one, which was detected in M. myristica, has been previously described in Artemisia annua, and this plant extract studied showed antioxidant, antimicrobial, and anti-inflammatory activities [50]. Ursodeoxycholic acid was identified in M. myristica, and this compound has been synthesized from a natural source [51]. Hexadecanoic acid contained in M. myristica has been described in many plants and this compound has good medicinal properties including anti-inflammatory, antioxidant, and enzyme inhibitory activities including anticholinesterase 
activity [52-54]. The compound 2-Hydroxy-4-methylbenzoic acid present in X. aethiopica has been detected previously in Hemidesmus indicus and mangrove fungus and has displayed anti-inflammatory, antipyretic, and antioxidant activities [55,56]. In the extract of X. aethiopica, abietic acid was identified, and this compound has been detected in Isodon wightii, which displayed antibacterial, antioxidant, and anticholinesterase activities [57]. A major component of eucalyptus called eucalyptol or 1,8-cineole identified in $X$, aethiopica extract has been detected in many species of eucalyptus, whose extracts possess antimicrobial and antiviral activities $[58,59]$. The volatile compound 3-carene was detected in the extract of X. aethiopica and has been described as an antimicrobial compound [60]. From these analyses of previous studies, it can be understood that the antimicrobial, antibiofilm, and enzyme inhibitory activities of these extracts of M. myristica and X. aethiopica can be attributed to these chemical compounds that they contain.

\section{Conclusions}

The investigation of bioactivities of food extracts and food-derived substances is attracting much attention because of their considerable and known safety. These food substances are exploited for their medicinal properties besides their nutritive values especially to combat food-borne infections resulting from various food pathogens. The emergence and spread of drug-resistant strains nowadays threatens the use of conventional antibiotics in order to treat bacterial infections and diseases. New strategies such as biofilm inhibition and quorum-sensing disruption are therefore necessary to overcome persistent infections especially those that involve resistant biofilm formation by the pathogens. Both food spices X. aethiopica and M. myristica have shown biofilm inhibitory potentials and also violacein inhibition and swimming/swarming motilities inhibitions. These traits are quorum-sensing-mediated processes which help to increase the resistance of bacteria and virulence of their infections. Both extracts displayed low to moderate anticholinesterase activities and tyrosinase and urease inhibitory potentials, which is interesting for these natural food spices. As an added value to the antimicrobial properties of these two natural food spices, they can be desirable as enzyme inhibitors which may present no or milder side effects than conventional synthetic drugs used for this purpose. The bioactivities of these extracts opens a space for the search of the bioactive molecules contained in them.

Author Contributions: Conceptualization, A.N.T. and O.C.; methodology, A.N.T., S.K., O.C., R.M.D., M.O. and M.E.D.; investigation, A.N.T., S.K. and O.C.; writing-original draft preparation, A.N.T. and O.C.; writing一review and editing, A.N.T., O.C. and R.M.D.; supervision, O.C., R.M.D., M.O. and M.E.D. Project administration, R.M.D.; funding acquisition, A.N.T. and R.M.D. All authors have read and agreed to the published version of the manuscript.

Funding: This research was funded by 'Agence Universitaire de la Francophonie' (AUF) and the Romanian Government through Eugen Ionescu Postdoctoral Mobility Program 2020.

Acknowledgments: The authors are grateful to the University of 'Dunarea de Jos' of Galati, Romania and Mugla Sitki Kocman University, Turkey for collaborative material support and for providing a conducive platform for this research.

Conflicts of Interest: The authors declare no conflict of interest.

\section{References}

1. Corn, C. Scents of Eden: A History of the Spice Trade; Kindasha: New York, NY, USA, 1999.

2. Chinenye, M.H. Antibacterial Activity of Piper Guineense, Xylopia Aethiopica and Allium Cepa Against Bacteria Isolated from Spoilt Soup Preparations. Ph.D. Thesis, University of Nigeria, Nsukka, Nigeria, 2014; p. 1.

3. Enabulele, S.A.; Oboh, F.O.J.; Uwadiae, E. Antimicrobial, nutritional and phytochemical properties of Monodora myristica seeds. IOSR J. Pharm. Biol. Sci. 2014, 9, 1-6. [CrossRef]

4. Okagu, I.U.; Ogugua, V.N.; Dibor, C.N.I.; Maryann, U.; Nnebe, M.E.; Aniehe, C.C.; Odenigbo, C.J.; Ngwu, U.E. Effects of methanol extraction on some nutritional and antinutrient contents of Xylopia aethiopica fruits from Enugu State, Nigeria. Asian J. Agric. Food Sci. 2018, 6, 84-96. [CrossRef] 
5. Tatsadjieu, L.N.; Essia-Ngang, J.J.; Nyassoum, M.B.; Etoa, F.X. Antibacterial and antifungal activity of Xylopia aethiopica, Monodora myristica, Xanthoxylum xanthoxyloides and Xanthoxylum leprieurii from Cameroun. Fitoterapia 2003, 74, 469-472. [CrossRef]

6. Tamfu, A.N.; Ozgur, C.; Godloves, C.F.; Mehmet, O.; Mehmet, E.D.; Farzana, S. Antibiofilm, antiquorum sensing and antioxidant activity of secondary metabolites from seeds of Annona senegalensis, Persoon. Mic Pathog 2020, 144, 104191. [CrossRef]

7. Erhirhie, O.; Moke, G.E. Xylopia Aethiopica: A Review of its ethnomedicinal, chemical and pharmacological properties earnest. Am. J. Pharm. Tech. Res. 2014, 4, 22-37.

8. Choumessi, T.A.; Danel, M.; Chassaing, S.; Truchet, I.; Penlap, V.B.; Pieme, A.C.; Asonganyi, T.; Ducommum, B.; Valette, A. Characterization of the anti-proliferative activity of Xylopia aethiopica. Cell Div. 2012, 7, 8-10. [CrossRef]

9. Adefegha, S.A.; Oboh, G. Effect of diets supplemented with Ethiopian pepper [Xylopia aethiopica (Dun.) A. Rich (Annonaceae)] and Ashanti pepper [Piper guineense Schumach. et Thonn (Piperaceae)] on some biochemical parameters in normal rats. Asian Pac. J. Trop. Biomed. 2012, 16, S558-S566. [CrossRef]

10. Soh, D.; Nkwengoua, E.; Ngantchou, I.; Nyasse, B.; Denier, C.; Hannaert, V.; Shaker, K.H.; Schneider, B. Xylopioxyde and other bioactive kaurane-diterpenes from Xylopia aethiopica Dunal (Annonaceae). J. Appl. Pharm. Sci. 2013, 3, 013-019.

11. Boampong, J.N.; Ameyaw, E.O.; Aboagye, B.; Asare, K.; Kyei, S.; Donfack, J.H.; Woode, E. The curative and prophylactic effects of xylopic acid on Plasmodium berghei infection in mice. J. Parasitol. Res. 2013, 2013, 356107.

12. Etoundi, C.B.; Kuate, D.; Ngondi, J.L.; Oben, J. Anti-amylase, anti-lipase and antioxidant effects of aqueous extracts of some Cameroonian spices. J. Nat. Prod. 2010, 3, 165-171.

13. Abd-Alg, N.N.; El-Kamali, H.H.; Ramadan, M.M.; Ghanem, K.Z.; Farrag, A.R.H. Xylopia aethiopica volatile compounds protect against panadol-induced hepatic and renal toxicity in male rats. World Appl. Sci. J. 2013, $27,10-22$.

14. Mohammed, A.; Islam, S.M. Antioxidant activity of xylopia aethiopica fruits acetone fraction in a type 2 diabetes model of rats. Biomed. Pharmacother. 2017, 96, 30-36. [CrossRef]

15. Weiss, E.A. Spice Crops; CABI Publishing: Oxon, UK, 2002; pp. 102-103.

16. Bakarnga-Via, I.; Hzounda, J.B.; Fokou, P.V.; Tchokouaha, L.R.; Gary-Bobo, M.; Gallud, A.; Garcia, M.; Walbadet, L.; Secka, Y.; Dongmo, P.M.; et al. Composition and cytotoxic activity of essential oils from Xylopia aethiopica (Dunal) A. Rich, Xylopia parviflora (A. Rich) Benth.) and Monodora myristica (Gaertn) growing in Chad and Cameroon. BMC Comp. Altern. Med. 2014, 14, 125. [CrossRef]

17. Nwozo, S.O.; Fowokemi, K.T.; Oyinloye, B.E. African nutmeg (Monodora myristica) lowers cholesterol and modulates lipid peroxidation in experimentally induced hypercholesterolemic male wistar rats. Int. J. Biomed. Sci. 2015, 11, 86-92.

18. Ogunmoyole, T.; Inaboya, S.; Makun, J.O.; Kade, I.J. Differential antioxidant properties of ethanol and water soluble phytochemicals of false nutmeg (Monodora myristica) seeds. Int. J. Biochem. Biotechnol. 2013, 2, 253-262.

19. Lekana-Douki, J.B.; Bongui, J.B.; Oyegue, L.S.L.; Zang-Edou, S.E.; Zatra, R.; Bisvigoua, U.; Druilhe, P.; Lebibi, J.; Ndouo, F.S.T.; Kombila, M. In vitro antiplasmodial activity and cytotoxicity of nine plants traditionally used in Gabon. J. Ethnopharmacol. 2011, 133, 1103-1108. [CrossRef]

20. Lacroix, D.; Prado, S.; Kamoga, D.; Kasenene, J.; Namukobe, J.; Krief, S.; Dumontet, V.; Mouray, E.; Bodo, B.; Brunois, F. Antiplasmodial and cytotoxic activities of medicinal plants traditionally used in the village of Kiohima, Uganda. J. Ethnopharmacol. 2011, 133, 850-855. [CrossRef]

21. Oyinloye, B.E.; Adenowo, A.F.; Osunsanmi, F.O.; Ogunyinka, B.I.; Nwozo, S.O.; Kappo, A.P. Aqueous extract of Monodora myristica ameliorates cadmium-induced hepatotoxicity in male rats. SpringerPlus 2016, 5, 641. [CrossRef]

22. Akinwunmi, K.F.; Oyedapo, O.O. In vitro anti-inflammatory evaluation of African nutmeg (Monodora myristica) seeds. Eur. J. Med. Plants. 2015, 8, 167-174. [CrossRef]

23. Ishola, I.O.; Ikumawoyi, V.O.; AfolayaN, G.O.; Olorife, O.J. Antinociceptive and anti-inflammatory properties of hydroethanolic seed extract of Monodora myristica (Annonaceae) in rodents. West Afr. J. Pharm. 2016, 27, 22-32. 
24. Nwankwo, P.O. Comparative study of the antioxidant activities of Monodora myristica and A. sceptrum on protein and lipid levels of diabetic-induced rats. IOSR J. Biotechnol. Biochem. 2015, 1, 63-71.

25. Agiriga, A.; Siwela, M. Monodora myristica (Gaertn.) Dunal: A plant with multiple food, health and medicinal applications: A review. Am. J. Food Technol. 2017, 12, 271-284. [CrossRef]

26. Talla, E.; Tamfu, A.N.; Gade, I.S.; Yanda, L.; Mbafor, J.T.; Sophie, L.; Vander-Elst, L.; Popova, M.; Bankova, V. New mono-ether of glycerol and triterpenes with DPPH radical scavenging activity from Cameroonian propolis. Nat. Prod. Res. 2017, 31, 1379-1389. [CrossRef] [PubMed]

27. Tamfu, N.A.; Jabeen, A.; Tagatsing, F.M.; Tariq, A.B.; Farzana, S. Organic and mineral composition of seeds of Afrostyrax lepidophyllus Mildbr. and evaluation of ROS inhibition and cytotoxicity of isolated compounds. Chem. Afr. 2019, 2, 615-624.

28. CLSI (Clinical Laboratory Standards Institute). Quality Control Minimal Inhibitory Concentration (MIC) Limits for Broth Dilution and MIC Interpretative Breakpoints (M27-s2); Clinical Laboratory of Standards Institute: Wayne, PA, USA, 2006.

29. Merritt, J.H.; Kadouri, D.E.; O'Toole, G.A. Growing and Analyzing Static Biofilms. Current Protocols in Microbiol; John Wiley \& Sons, Inc.: Hoboken, NJ, USA, 2005.

30. Packiavathy, I.A.S.V.; Agilandeswari, P.; Musthafa, K.S.; Pandian, S.K.; Ravi, A.V. Antibiofilm and quorum sensing inhibitory potential of Cuminum cyminum and its secondary metabolite methyl eugenol against Gram negative bacterial pathogens. Food Res. Int. 2012, 45, 85-92. [CrossRef]

31. Ellman, G.L.; Courtney, K.D.; Andres, V.; Featherstone, R.M. A new and rapid colorimetric determination of acetylcholinesterase activity. Biochem. Pharmacol. 1961, 7, 88-95. [CrossRef]

32. Khattak, S.; Saeed-Ur-Rehman, S.; Khan, T.; Ahmad, M. In vitro enzyme inhibition activities of crude ethanolic extracts derived from medicinal plants of Pakistan. Nat. Prod. Res. 2005, 19, 567-571. [CrossRef] [PubMed]

33. Weatherburn, M.W. Phenol-hypochlorite reaction for determination of ammonia. Anal. Chem. 1967, 39, 971-974. [CrossRef]

34. Kuete, V. Potential of Cameroonian plants and derived products against microbial infections. Planta Med. 2010, 76, 1479-1491. [CrossRef]

35. Olusimbo, O.A.; Abimbola, R.E.; Chinonye, L.A. Antimicrobial activities of some Nigerian spices on some pathogens. Agric. Biol. J. N. Am. 2011, 2, 1187-1193.

36. Costerton, J.W.; Stewart, P.S.; Greenberg, E.P. Bacterial biofilms: A common cause of persistent infections. Science 1999, 284, 1318-1322. [CrossRef] [PubMed]

37. De Vasconcelos, A.T.R.; De Almeida, D.F.; Hungria, M.; Guimarães, C.T.; Antonio, R.V.; Almeida, F.C.; De Almeida, L.G.; De Almeida, R.; Alves-Gomes, J.A.; Andrade, E.M.; et al. The complete genome sequence of Chromobacterium violaceum reveals remarkable and exploitable bacterial adaptability. Proc. Natl. Acad. Sci. USA 2003, 100, 11660-11665.

38. Kothari, V.; Sharma, S.; Padia, D. Recent research advances on Chromobacterium violaceum. Asian Pac. J. Trop. Med. 2017, 10, 744-752. [CrossRef] [PubMed]

39. O'May, C.; Tufenkji, N. The swarming motility of Pseudomonas aeruginosa is blocked by cranberry proanthocyanidins and other tannin-containing materials. Appl. Environ. Microbiol. 2011, 77, 3061-3067. [CrossRef] [PubMed]

40. Sharma, K. Cholinesterase inhibitors as Alzheimer's therapeutics (Review). Mol. Med. Reports. 2019, 20, 1479-1487. [CrossRef] [PubMed]

41. Chang, T.S. An updated review of tyrosinase inhibitors. Int. J. Mol. Sci. 2009, 10, 2440-2475. [CrossRef] [PubMed]

42. Svane, S.; Sigurdarson, J.J.; Finkenwirth, F.; Eitinger, T.; Karring, H. Inhibition of urease activity by different compounds provides insight into the modulation and association of bacterial nickel import and ureolysis. Sci. Rep. 2020, 10, 8503. [CrossRef]

43. Altameme, H.J.; Hameed, I.H.; Kareem, M.A. Analysis of alkaloid phytochemical compounds in the ethanolic extract of Datura stramonium and evaluation of antimicrobial activity. Afr. J. Biotechnol. 2015, 14, 1668-1674.

44. Mohammed, A.B.; Hafiz, A.M.; Hassan, A.A.; Sohier, M.S.; Ashraf, N.A.; Husham, E.H.; Shahnaz, S.; Waquar, A.; Asaad, K. Phytochemical, Cytotoxic, and Antimicrobial Evaluation of the Fruits of Miswak Plant, Salvadora persica L. J. Chem. 2020, 2020, 4521951. 
45. Selwyn, S.; Durodie, J. The antimicrobial activity of sugar against pathogens of wounds and other infections of man. In Properties of Water in Foods; Simatos, D., Multon, J.L., Eds.; NATO ASI Series (Series E: Applied Sciences); Springer: Dordrecht, The Netherlands, 1985; Volume 90, pp. 293-308.

46. Singh, B.R. Antibacterial Activity of Glycerol, Lactose, Maltose, Mannitol, Raffinose and Xylose. Med. Noto-Are 2014, 2014, 17223318.

47. Bisignano, G.; Sanogo, R.; Marino, A.; Aquinol, R.; D’Angelo, V.; Germano, M.P.; De-Pasquale, R.; Pizza, C. Antimicrobial activity of Mitracarpus scaber extract and isolated constituents. Lett. Appl. Microbiol. 2000, 30, 105-108. [CrossRef] [PubMed]

48. Katsure, S.V.; Suvarna, A.K.; Dhiraj, M.; Rupali, W.; Mahalaxmi, M.; Sanjay, B.K. Antioxidant and Antiparkinson Activity of Gallic Acid Derivatives. Pharmacologyonline 2009, 1, 385-395.

49. Vennila, V.; Udayakumar, R. GC-MS Analysis of Leaf, Fruits and Latex of Croton bonplandianum Baill. Int. J. Biochem. Res. Rev. 2015, 5, 187-197. [CrossRef]

50. Hameed, I.H.; Altameme, H.J.; Idan, S.A. Artemisia annua: Biochemical products analysis of methanolic aerial parts extract and anti-microbial capacity. Res. J. Pharm. Biol. Chem. Sci. 2016, 7, 1843-1868.

51. Wang, J.; Gu, X.-Z.; He, L.-M.; Li, C.-C.; Qiu, W.-W. Synthesis of ursodeoxycholic acid from plant-source (20S)-21-hydroxy-20-methylpregn-4-en-3-one. Steroids 2020, 157, 108600. [CrossRef]

52. Zhe, F.; Su, Y.J.; Hyun, A.J.; Jae, S.C.; Byung, S.M.; Mi, H.W. Anticholinesterase and Antioxidant Constituents from Gloiopeltis furcate. Chem. Pharm. Bull. 2010, 58, 1236-1239.

53. Mustapha, N.A.; Runner, R.T.M. GC-MS Analysis and Preliminary Antimicrobial Activity of Albizia adianthifolia (Schumach) and Pterocarpus angolensis (DC). Medicines 2016, 3, 3.

54. Krishnan, K.; James, R.F.; Mohan, A. Isolation and characterization of n-hexadecanoic acid from Canthium parviflorum leaves. J. Chem. Pharm. Res. 2016, 8, 614-617.

55. Mahalingam, G.; Krishnan, K. Antidiabetic activity of 2-hydroxy 4-methoxy benzoic acid isolated from the roots of Hemidesmus indicus on streptozotocin-induced diabetic rats. Int. J. Diabetes Metabol. 2009, 17, 53-57.

56. Shao, C.; Guo, Z.; Peng, H.; Peng, G.; Huang, Z.; She, Z.; Lin, Y. A new isoprenyl phenyl ether compound from mangrove fungus. Chem. Nat. Compd. 2007, 43, 377-380. [CrossRef]

57. Ramnath, M.G.; Thirugnanasampandan, R.; Sadasivam, M.; Mohan, P.S. Antioxidant, antibacterial and antiacetylcholinesterase activities of abietic acid from Isodon wightii (Bentham) H. Hara. Free Rad. Antiox. 2015, 5, 1-5. [CrossRef]

58. Elaissi, A.; Rouis, Z.; Salem, N.A.; Mabrouk, S.; Ben-Salem, Y.; Salah, K.B.; Aouni, M.; Farhat, F.; Chemli, R.; Harzallah-Skhiri, F.; et al. Chemical composition of 8 eucalyptus species' essential oils and the evaluation of their antibacterial, antifungal and antiviral activities. BMC Complement. Altern. Med. 2012, 12, 81. [CrossRef] [PubMed]

59. Clavijo-Romero, A.; Quintanilla-Carvajal, M.X.; Ruiz, Y. Stability and antimicrobial activity of eucalyptus essential oil emulsions. Food Sci. Technol. Int. 2018, 25, 24-37. [CrossRef] [PubMed]

60. Huizhen, S.; Haiming, C.; Xiaolong, W.; Yueying, H.; Yonghuan, Y.; Qiuping, Z.; Weijun, C.; Wenxue, C. Antimicrobial Activity and Proposed Action Mechanism of 3-Carene against Brochothrix thermosphacta and Pseudomonas fluorescens. Molecules 2019, 24, 3246.

Publisher's Note: MDPI stays neutral with regard to jurisdictional claims in published maps and institutional affiliations.

(C) 2020 by the authors. Licensee MDPI, Basel, Switzerland. This article is an open access article distributed under the terms and conditions of the Creative Commons Attribution (CC BY) license (http://creativecommons.org/licenses/by/4.0/). 